Transportation and Communications, Report RR135: 67 pp.

FROMM, H. J. (1971). The Effects of Deicing Chemicals on the Environment. Ontario Ministry of Transportation and Communications, Report 1R43: 4 pp.

HANES, R. E. (1970). Salt Tolerance of Trees and Shrubs to Deicing Salts. National Co-operative Highway Res. Program Report No. 335. (Hwy Res. Bd.) [not available for checking] .

HAWKINS, R. H. (1971). Street Salting and Water Quality in Meadowbrook, Syracuse, New York. Proceedings of the Street Salting Urban Water Quality Workshop, University of Syracuse; Syracuse, NY: [not available for checking].

HAWKINS, R. H. \& JUDD, J. H. (1972). Water pollution as affected by street salting. Water Resources Bulletin, 8 (6), p. 1246.

HOFSTRA, G. \& HALL, R. (1971). Injury on roadside trees: leaf injury on pine and white cedar in relation to foliar levels of sodium chloride. Can. J. Bot., 49, pp. 613-22.

HULING, E. E. \& HOLLOCHER, T. C. (1972). Groundwater contamination by road salt: steady-state concentrations in east-central Massachusetts. Science, 176, pp. 288-90.

JOY, M. (1979). A Study of the Sodium in Private Domestic Wells in a Selected Area of York Region. Institute for Environmental Studies, University of Toronto, Working Paper Pub. No. SIC-6, 17 pp.
KELLY, W. P. (1963). Use of saline irrigation water. Soil Sci., 95, pp. 385-91.

MANNING, D. G. \& RYELL, J. (1976). Durable Bridge Decks. Ontario Ministry of Transportation and Communications, Research and Development Branch, $67 \mathrm{pp}$.

MURRAY, D. M. \& ERNST, U. F. W. (1976). An Economic Analysis of the Environmental Impact of Highway Deicing. Report No. EPA 600/2 76-105, U.S. Environmental Protection Agency, Washington, DC: $128 \mathrm{pp}$.

PAINE, R. (1979). Chlorides in the Don River Watershed Resulting from Road Deicing Salt. Institute for Environmental Studies, University of Toronto, SIC-3, $23 \mathrm{pp}$.

RALSTON, J. G. (1971). Deicing Salt as a Source of Water Pollution. Ontario Ministry of the Environment, Water Quality Branch, 8 pp.

SCOTT, W. S. (1976). The Effect of Road Deicing Salts on Na and Cl Levels in Two Metro Toronto Stream Systems. York University Master's Thesis, Toronto, Ontario, $227 \mathrm{pp}$., mimeogr.

SUCOFF, E. \& WONG, S. G. (1976). Effect of $\mathrm{NaCl}$ on cold hardiness of Malus spp. and Syringa vulgaris. Can. J. Bot., 54, pp. 2816-9.

TERRY, R. G. (1974). Road Salt, Drinking Water and Safety. Ballinger, Cambridge, Massachusetts: $161 \mathrm{pp}$.

VALLENTYNE, J. R. (1979). Road salt and the Great Lakes: an ecological lesson. Queen's Quarterly, October, p. 429.

\title{
Saudi Arabia makes Major Commitment to Conservation
}

Saudi Arabia recently signed a major agreement with the International Union for Conservation of Nature and Natural Resources (IUCN) which marks the beginning of a new drive to conserve the country's wildlife and other natural resources. Under the terms of the new agreement, IUCN will provide expert guidance to Saudi Arabia on how to go about protecting and managing its natural resources.

After signing (Fig. 1) the one million Rial (U.S. $\$ 300,000)$ Trust Fund Agreement with Saudi Arabia's Meteorology and Environmental Protection Agency (MEPA), IUCN's Director-General said, 'The signing of this Agreement is an historic occasion because it represents the start of a new era of cooperation between IUCN and Saudi Arabia. The first job for our experts is to identify the priorities-once this is done, the work of effective resource management can begin'. A plan for a national conservation strategy, a blueprint for a programme to protect endangered species, and legal and environmental education advice, are all included in the undertaking which IUCN has made with MEPA.

Dr Al-Gain, MEPA's Deputy Director, commented: 'The Koran and Arabic poetry attach great importance to the value to Man of preserving his natural heritage; so this Agreement will support our efforts to renew the interest in conservation in Saudi Arabia. IUCN's experts will help us to devise ways of combining the traditional Islamic respect for Nature with the most up-to-date environmental management techniques'**

Under the terms of the Agreement, IUCN will provide assistance to MEPA on:

- Setting up a network of protected areas;

- Training Saudi Arabians in wildlife management;

- Improving the Government's legal capacity;

-Establishing a Department of Natural Resources; -Incorporating conservation aims into development

*See our comment and suggestion at the foot of page 21 of this issue. - Ed.

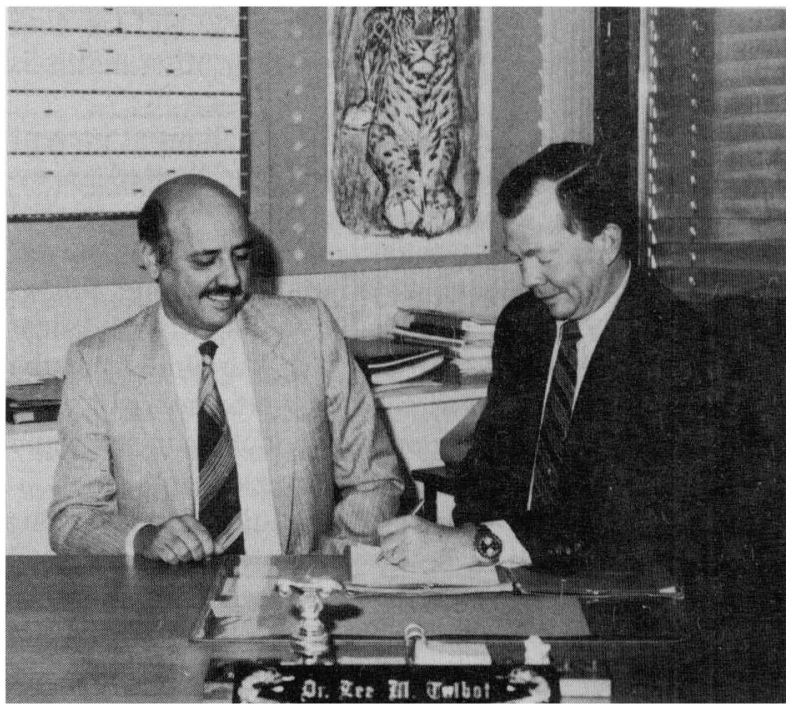

Fig. 1. IUCN: Director-General, Dr Lee M. Talbot, signing the Trust Fund Agreement at Gland on 14 November 1980. Photo: Michèle Dépraz.

planning through the drawing up of a national conservation strategy; and

-Conserving endangered species such as the Houbara Bustard (Chlamydotis undulata) and the Arabian Oryx (Oryx leucoryx).

Robert Lamb, Editor of IUCN B: lletin
International Union for Conservation of
Nature and Natural Resources
Avenue du Mont-Blanc
1196 Gland
Switzerland.

